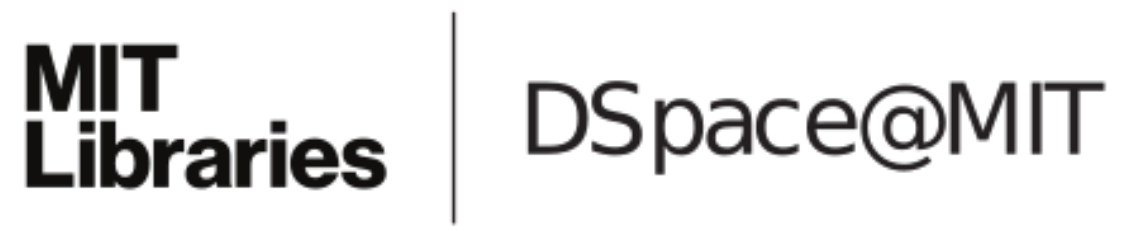

\author{
MIT Open Access Articles
}

Telecommunications Deregulation

The MIT Faculty has made this article openly available. Please share how this access benefits you. Your story matters.

Citation: Hausman, Jerry A, and William E Taylor. "Telecommunications Deregulation." American Economic Review 102, no. 3 (May 2012): 386-390. (c) 2012 the American Economic Association

As Published: http://dx.doi.org/10.1257/aer.102.3.386

Publisher: American Economic Association

Persistent URL: http://hdl.handle.net/1721.1/82653

Version: Final published version: final published article, as it appeared in a journal, conference proceedings, or other formally published context

Terms of Use: Article is made available in accordance with the publisher's policy and may be subject to US copyright law. Please refer to the publisher's site for terms of use. 


\title{
Telecommunications Deregulation
}

\author{
By Jerry A. Hausman and William E. Taylor*
}

\begin{abstract}
"The case of telecommunications is so much more complicated than that of the airlines, I am deterred to the point of muteness - well, not quite - by the challenge of sorting out what ought to happen next."
\end{abstract}

(Kahn 2004, p. 21)

In 1970, when Fred Kahn's magisterial volumes of The Economics of Regulation first appeared, telecommunications in the United States was unrecognizably different from today. Services were supplied by pervasively regulated monopolistslargely AT\&T and the Bell System for wireline local (80 percent) and long-distance services (near 100 percent). For practical purposes, data and wireless communications did not exist. Competitive entry for local and long-distance voice services was forbidden, service characteristics and quality were prescribed and prices were set (more or less) by cost-plus, rate-of-return regulation, administered by the Federal Communications Commission (FCC) for interstate (long distance) services and by state public-utility commissions for local and intrastate long-distance services. This regulation was justified by presumed natural monopoly characteristics of parts of the industry. In contrast to the airline regulation, which was "government cartelization, plain and simple ... telecommunications regulation ... has been much more clearly and directly aimed at the protection of putatively captive customers from putative natural monopolies" (Kahn 2006b, p. 6).

Forty years have passed, and the landscape has changed. In Kahn's words, “... [t] he industry is obviously no longer a natural monopoly and wherever there is effective competition-typically and most powerfully, between competing

\footnotetext{
*Hausman: MIT Department of Economics, 50 Memorial Drive, Cambridge, MA 02142 (e-mail: jhausman@mit.edu); Taylor: NERA, 200 Clarendon St., Boston, MA 02116 (e-mail: william.taylor@nera.com). We thank Roger Noll, Tim Tardiff, and Dennis Weisman for useful comments. Both authors have consulted for numerous telephone companies.

${ }^{\dagger}$ To view additional materials, visit the article page at http://dx.doi.org/10.1257/aer.102.3.386.
}

platforms-land-line telephony, cable and wireless-regulation of the historical variety is both unnecessary and likely to be anticompetitive" (Kahn 2007, p. 1).

The path from then to now was tumultuous, driven by technological change (wireless, fiber, cable telephony) and featuring a (regulatoryinduced) gold-rush-style entry and collapse of competitors, an industry-wide vertical divestiture largely offset by a subsequent merger wave, regulatory innovation (incentive regulation), industry restructuring legislation (the 1996 Telecom Act) and reregulatory initiatives (regulated pricing of network elements, network neutrality). But Kahn's observation above is the key to change and competition in telecommunications: it was facilities-based competition that drove technological change and increased consumer welfare. The experience from 1970 to the present shows that attempted regulation and "sharing" of privately owned network facilities is second best, and would be third best if there were an alternative second best.

It is impossible in this space to detail Kahn's contributions to this history. Several themes, however, pervade his work. Prices must be informed by costs; costs are actual incremental costs; costs and prices are an outcome of a Schumpeterian competitive process, not the starting point; excluding firms from markets is anticompetitive; a reliance on imperfect markets subject to antitrust law is preferable to necessarily imperfect regulation; and a regulatory transition to deregulation entails propensities to micromanage the process to generate preferred outcomes, visible competitors, and expedient price reductions. We expand on some of these ideas below.

\section{Incremental Costs}

Using prices to elicit supply and regulate demand and adjusting those prices towards costs is an economically sensible program for a regulator. At the New York Public Service Commission in the 1970s, Kahn showed skeptics 
that nonzero usage prices for business and residential local service and-famously-for directory assistance would significantly affect usage volumes and increase social welfare. The next step, adjusting regulated prices toward costs, was more difficult, first because multiproduct telecommunications firms had important economies of scale and scope (Kahn and Shew 1987) and, second, because the Supreme Court in Smith v. Illinois Bell in 1930 insisted that some portion of the cost of local facilities be recovered from long-distance services that used the local loop to originate and terminate calls.

Efficient pricing of basic local-exchange service and carrier-access services hinged on the economic cost of the local loop. Because additional usage imposes no additional costs on the loop, the marginal cost of usage includes no assignment of loop costs, no matter how reasonable the allocators proposed by advocates of low local prices and high long-distance and carrier-access prices. As Kahn and Taylor (2002, p. 9) put it, "It might be equally reasonable to allocate railroad overhead costs to services by volume, weight or value, but shippers of feathers, coal and diamonds would undoubtedly disagree about the results."

The futility of artificially allocating costs was vividly expressed in Kahn's regulatory analogue of Schrödinger's cat: "Once you abandon marginal cost, it is not difficult to find another measure of cost ... it is hopeless. This is not a question of looking for a black cat in a room where all the lights have been turned out. There is no cat there" (Kahn 1984, p. 12).

If regulators, courts, and the Department of Justice (DOJ) had understood this basic point, telecommunications history in the US would have been much different. The belief that monopoly local service cross-subsidized competitive longdistance service would not have been an element of the government antitrust case and the subsequent litigation before Judge Harold Greene. Regional Bell Operating Companies' (RBOC's) cellular companies would have been able to provide long-distance service, and the RBOCs would have been allowed to enter long-distance markets well before their permitted entry (state by state between 1999 and 2003).

\section{Entry Restrictions}

Between 1984 and 1996, local telephone companies' participation in manufacturing, information services, and long distance was controlled by the court under Judge Greene. Kahn observed that "[b]ecause the restrictions on the uses to which the BOCs may put their own technology are both anticompetitive and countertechnological ... those restrictions will not survive many more years" (Kahn 1987, p. 1060).

The costs of these entry restrictions were enormous. Lost consumer surplus from restrictions on BOC provision of voice mail alone cost consumers approximately $\$ 1.2$ billion per year (Hausman 1997). Restrictions on BOC provision of longdistance services were even more costly, amounting to tens of billions of dollars in lost consumer welfare (Hausman, Leonard, and Sidak 2002).

Putative benefits of entry restrictions faded quickly due to technical change (optical fiber transmission, computer-controlled switching, and wireless technology), which allowed entry of competing firms for local telephone service and doomed long-distance providers such as AT\&T and MCI..$^{1}$ Nevertheless, FCC and DOJ policies attempted to protect these companies from RBOC competition in the mistaken belief that they would be viable local competitors, rather than the wireless or cable companies. ${ }^{2}$

\section{The Path to Deregulation}

As telecommunications markets opened to competition, the inherent inconsistency with rate-ofreturn regulation became apparent. Breaking the link between regulated prices and costs, Vermont replaced traditional regulation with a social contract in 1987, followed shortly by the FCC, which introduced price-cap regulation of long-distance and carrier-access services in 1988-89. Many states followed suit during the 1980s and 1990s.

Most of these incentive-regulation plans included such vestiges of rate-of-return regulation as scheduled rate-of-return reviews, earnings-sharing backstops, and other mitigations. Before the FCC, Kahn pointed out the defective incentives of these mitigations, concluding that "... $[\mathrm{t}]$ he longer the interval between

\footnotetext{
${ }^{1}$ None of these changes was considered by Judge Greene because they postdated the record in the case.

${ }^{2}$ Hausman predicted in a talk given in 1995 that AT\&T would not exist in ten years' time. He was off in his prediction by one month. Thus, the world's largest corporation disappeared in less than 25 years from the time of the modification of final judgment.
} 
reexaminations of the price caps and the wider the range of achieved rates of return that regulators, the utility companies and the public can tolerate, the closer will be the approximation to the workings of competition" (Kahn 1994, p. 18).

In addition, where circumstances warranted, Kahn called for pricing flexibility, for deregulation of discretionary or structurally separated retail services, and for regulatory forbearance in the presence of facilities-based competition.

\section{Reregulation: TELRIC-BS}

This deregulatory trend was partially reversed after 1996, when, in acts of "astounding regulatory presumption" in establishing wholesale prices pursuant to the Telecommunications Act, the FCC and state regulators succumbed to the "temptations of the kleptocrats," ignoring the lessons from years of experience with price-cap regulation and "reneging on obligations to allow utilities to recover their historical costs when those obligations stood in the way of politically expedient rate reductions" (Kahn 2004, p. 30).

As implemented by the FCC and state regulators, the Telecommunications Act was essentially a "competitor protection" act, setting below-cost prices for competitors' use of the incumbents' networks and restricting RBOC entry into long distance. Below-cost regulated pricing created incentives for new entrants to use unbundled RBOC network elements rather than invest in their own competing facilities. This incentive increased when the FCC mandated the unbundled network element platform (UNE-P) at regulated prices, which permitted competitors to use an entire RBOC network (combined loops and switches) at below-cost prices, spawning a gold rush-style entry in the late 1990s.

Kahn's memorable contribution to this debate was his blistering condemnation of the FCC's pricing policy for unbundled network elements, set equal to "the costs of an 'efficient firm' constructing its network afresh, using the latest, best technology" which Kahn dubbed "total element long run incremental cost, blank slate" (TELRIC-BS). According to Kahn, “...[i]nvestments made today, totally embodying the most modern technology available, currently, would instantaneously be outdated tomorrow and, in consequence, fail over their lifetimes to earn a return sufficient to justify the investments in the first place" (Kahn, Tardiff, and Weisman 1999, pp. 325-26).
In February 2003, the FCC substantially upheld its UNE-P plan in its universally reviled Triennial Review Order. ${ }^{3}$ Fortunately, in 2004, UNE-P was overturned by the US Court of Appeals-DC Circuit, which determined that because competitors were able to provide their own switching services, they were not entitled to purchase price-regulated UNE-Ps. The most prominent local competitors, MCI and AT\&T (the long distance company), soon disappeared by merger in 2005, and local and long-distance residential competition shifted rapidly to cable and wireless companies: by the end of 2010 , approximately 30 percent of residential users subscribed to cable telephone (FCC 2011) and 28 percent subscribed only to cellular service (Blumberg and Luke 2011). Competition is thriving today, but it comes from facilities-based competitors, not from "artificial competition," as Justice Breyer characterized the regulatory-based approach of the FCC and DOJ (Breyer 1999).

In the same schizophrenic 2003 Triennial Review Order that retained UNE-P, the FCC (by a 3-2 majority) exempted next-generation fiber facilities from unbundling and sharing requirements. Almost immediately, the two major landline telephone companies Verizon and SBC (now AT\&T) began construction of residential fiber optic networks, commencing service in 2005 , and cable investment in telephony infrastructure soared. Thus, only after artificial competition was rolled back from both voice and broadband services did facilities-based competition begin to replace regulation in residential telecommunications markets.

\section{Reregulation: Network Neutrality}

The final chapter in Kahn's contribution to telecommunications deregulation was his stand against reregulation of broadband access to the internet. Proponents of such regulation focused on two issues: discrimination by broadband networks against (i) competitors of their other services (e.g., Vonage, Netflix, or BitTorrent) and (ii) different content providers (e.g., Google or Amazon) by offering traffic prioritization for a

\footnotetext{
3 “... the decision is an abomination, purely political in the worst sense of the term and grounded in neither good economics nor honorable regulatory practice. The one safe prediction is that it will turn out to have resolved little or nothing" (Kahn 2003, p. 1).
} 
price. To the first issue, Kahn pointed out that the antitrust laws prohibited such discrimination and that regulatory authorities had promptly intervened in the few instances where it was alleged. To the second, Kahn pointed out that nondiscrimination does not imply a single class of service but rather the same price for the same service quality: television stations charge different rates for access to their audiences depending on their anticipated size (Kahn 2006a, 2007).

\section{Conclusion}

Kahn's contributions to telecommunications spanned three eras of regulation and deregulation: the pre-MFJ FCC, Judge Greene and the DOJ, and the FCC after the 1996 Telecommunications Act. In each era, experience showed that facilitiesbased imperfect competition (and it can be highly imperfect) provided greater consumer welfare than imperfect regulation. As Kahn said 32 years ago in his Richard T. Ely lecture at the American Economic Association's annual meeting,

Our uncertainty about the outcome of the competitive struggle is no reason to prevent its taking place; ... if we cannot predict how these offsetting advantages and handicaps of the several carriers are likely to work out under a regime of free entry, it seems to me even less likely that we can hope to achieve the most efficient performance... by prescribing how the thousands of markets should be served... I find it difficult to see how these uncertainties tilt the balance in the direction of a reliance on predictably ignorant regulation in preference to an uncertainly predictable market process (Kahn 1979, p. 6).

We hope this lesson will not be forgotten in the future.

\section{REFERENCES}

Blumberg, Steven J., and Julian V. Luke. 2011. "Wireless Substitution: Early Release of Estimates from the National Interview Health Survey, July-December 2010." Centers for Disease Control and Prevention, June 8.

Breyer, Stephen. 1999. AT\&T Corp. v. Iowa Utilities Board, 119 S. Ct. 721.
Federal Communications Commission, Industry Analysis and Technology Division, Wireline Competition Bureau. 2011. Local Telephone Competition: Status as of December 31, 2010. Washington, DC: Federal Communications Commission.

Hausman, Jerry A. 1997. "Valuing the Effect of Regulation on New Services in Telecommunications." Brookings Papers on Economic Activity: 1-38.

Hausman, Jerry A., Gregory K. Leonard, and J. Gregory Sidak. 2002. "Does Bell Company Entry into Long-Distance Telecommunications Benefit Consumers?" Antitrust Law Journal 70: 463-84.

Kahn, Alfred E. 1979. "Applications of Economics to an Imperfect World." American Economic Review 69 (2): 1-13.

-Kahn, Alfred E. 1984. "The Uneasy Marriage of Regulation and Competition." Telematics 1: $1-2,8-17$.

-Kahn, Alfred E. 1987. "Deregulatory Schizophrenia," California Law Review 75 (3): 1059-68.

Kahn, Alfred E. 1994. Notice of Proposed Rulemaking. "Affidavit." In The Matter of Price Cap Review for Local Exchange Carriers, Notice of Proposed Rulemaking, FCC CC Docket No. 94-1, filed June 28. Washington, DC: Federal Communications Commission.

Kahn, Alfred E. 2003. "Regulatory Politics as Usual." American Enterprise Institute-Brookings Joint Center for Regulatory Studies Working Paper 03-3.

Kahn, Alfred E. 2004. Lessons from Deregulation: Telecommunications and Airlines after the Crunch. Washington, DC: American Enterprise Institute-Brookings Joint Center for Regulatory Studies.

Kahn, Alfred E. 2006a. "A Democratic Voice of Caution on Network Neutrality." The Progress \& Freedom Foundation, Release 2.24.

Kahn, Alfred E. 2006b. "Telecommunications, the Transition from Regulation to Antitrust." American Enterprise Institute-Brookings Joint Center for Regulatory Studies 06-21.

Kahn, Alfred E. 2007. "Network Neutrality." American Enterprise Institute-Brookings Joint Center for Regulatory Studies 07-05.

Kahn, Alfred E., and William B. Shew. 1987. "Current Issues in Telecommunications Regulation: Pricing." Yale Journal on Regulation 4 (2): 191-256.

Kahn, Alfred E., and William E. Taylor. 2002. 
"Declaration of Alfred E. Kahn and William E. Taylor on Behalf of BellSouth Corporation, Qwest Corporation, SBC Communications, Inc., and Verizon." RM No. 10593, filed December 2. Washington, DC: Federal Communications Commission.
Kahn, Alfred E., Timothy J. Tardiff, and Dennis L. Weisman. 1999. "The Telecommunications Act at Three Years: An Economic Evaluation of Its Implementation by the Federal Communications Commission." Information Economics and Policy 11 (4): 319-65. 